\title{
Contact activation in the extrinsic blood clotting system
}

Citation for published version (APA):

Altman, R., \& Hemker, H. C. (1967). Contact activation in the extrinsic blood clotting system. Thrombosis et diathesis haemorrhagica, 18(3-4), 525-531. https://doi.org/10.1055/S-0038-1655061

Document status and date:

Published: 01/01/1967

DOI:

10.1055/S-0038-1655061

Document Version:

Other version

\section{Please check the document version of this publication:}

- A submitted manuscript is the version of the article upon submission and before peer-review. There can be important differences between the submitted version and the official published version of record.

People interested in the research are advised to contact the author for the final version of the publication, or visit the DOI to the publisher's website.

- The final author version and the galley proof are versions of the publication after peer review.

- The final published version features the final layout of the paper including the volume, issue and page numbers.

Link to publication

\footnotetext{
General rights rights.

- You may freely distribute the URL identifying the publication in the public portal. please follow below link for the End User Agreement:

www.umlib.nl/taverne-license

Take down policy

If you believe that this document breaches copyright please contact us at:

repository@maastrichtuniversity.nl

providing details and we will investigate your claim.
}

Copyright and moral rights for the publications made accessible in the public portal are retained by the authors and/or other copyright owners and it is a condition of accessing publications that users recognise and abide by the legal requirements associated with these

- Users may download and print one copy of any publication from the public portal for the purpose of private study or research.

- You may not further distribute the material or use it for any profit-making activity or commercial gain

If the publication is distributed under the terms of Article $25 \mathrm{fa}$ of the Dutch Copyright Act, indicated by the "Taverne" license above, 


\section{THROMBOSIS ET DIATHESIS HAEMORRHAGICA}

EDITORES: K. M. BRINKHOUS, CHAPEL HILL; F. BÜCHNER, FREIBURG/BREISGAU; E. DEUTSCH, WIEN; J. E. JORPES, STOCKHOLM; F. KOLLER, BASEL; J. ROSKAM, LIÈGE; J.-P. SOULIER, PARIS; I. S. WRIGHT, NEW YORK

\section{Contact Activation in the Extrinsic Blood Clotting System}

From the Haematology Section of the Department of Internal Medicine, University Hospital, Leyden (The Netherlands)

R. Altman* and H. C. Hemker

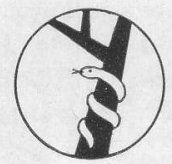

F. K. SCHATTA UER - VERLAG - STUTTGART 
Two reaction sequences of blood coagulation are currently recognized. The intrinsic pathway comprises factors XII, XI, IX, VIII, X, V, II, and I; the extrinsic pathway shares factors X, V, II, and I with the intrinsic, and also includes factor VII. The intrinsic pathway is thought to be triggered by contact of factor XII with a wettable surface, whereas the reactions of the extrinsic pathway are initiated by the action of "tissue factor" on factor VII.

During an investigation into the kinetics of the extrinsic system as measured by the thrombotest method, contact with a wettable surface was found to shorten the clotting times in this system (1). This phenomenon has already been described (2), but since agreement has not been reached concerning the responsible mechanism, it seemed worthwhile to investigate th is particular point further.

\section{Materials and Methods}

All plasmas (normal as well as congenitally deficient) were prepared contact-free, centrifuged for 30 min at $30,000 \mathrm{~g}$, and then stored at $-20^{\circ} \mathrm{C}$ in plastic tubes.

Factor $V$-poor plasma was prepared by storing normal oxalated plasma at $37^{\circ} \mathrm{C}$. The clottingfactor contents of this plasma were; factor II: $75 \%$; factor VII : $62 \%$; factor X: $50 \%$; factor V $<1 \%$.

Ba-stearate-absorbed plasma is normal citrate plasma treated with $50 \mathrm{mg} / \mathrm{ml} \mathrm{Ba-stearate} \mathrm{(K \text {and }}$ K laboratories Inc., Plain View, N. Y., U. S.A.; lot 45884 L) for 10 min at $37^{\circ}$ C, and centrifuged for $10 \mathrm{~min}$ at $30,000 \mathrm{~g}$. This plasma contained: factor II: $80 \%$; factor VII: $105 \%$; factor V: $8 \%$; factor XII: $100 \%$, and no measurable amount of factor XI (3).

Exhausted plasma was prepared according to Nossel (4) by admixture of $30 \mathrm{mg} / \mathrm{ml}$ of celite (Hyflo Super-cel, Johns-Manville, N.Y., U.S.A.) before centrifugation, or by treatment with $5 \mathrm{mg} / \mathrm{ml}$ of celite only.

PTA-deficient plasma was a gift from Dr. S. I. de Vries, Wilhelminagasthuis, Amsterdam (5). Improved PTA-deficient plasma was prepared from this plasma according to Soulier and Prou Wartelle (6).

Contact product (C.P.) was prepared according to Niewiarowski (7) using celite as absorbent. The preparation contained traces of factor II (3\%), factor VII $(6 \%)$, and factor X $(3 \%)$. An activity of $100 \%$ of this preparation was defined as the activity that, when twice diluted, caused the same clotting time as a suspension of celite $(10 \mathrm{mg} / \mathrm{ml})$ in the following reaction mixture: normal plasma $0.2 \mathrm{ml}$; phospholipid suspension $0.1 \mathrm{ml}$; C. P. or celite suspension $0.1 \mathrm{ml} ; \mathrm{CaCl}_{2} 25 \mathrm{mM} 0.1 \mathrm{ml}$.

Heated C.P. was prepared by heating the C.P. for $30 \mathrm{~min}$ at $65^{\circ} \mathrm{C}$ in a water bath.

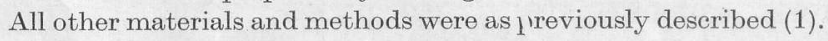

*) Present address: Rivadavia Hospital, Buenos Aires, Argentina.

Thrombos. Diathes. haemorrh. (Stuttg.) 


\section{Experimental Results}

The basic test of this investigation consisted of incubation at $37^{\circ} \mathrm{C}$ of a plasma diluted 1 in 10 with buffer, with or without various admixtures. At given times a 0.05 aliquot of this plasma was subsampled into $0.25 \mathrm{ml}$ thrombotest reagent. The clotting time thus obtained was plotted against the incubation time. To describe the activation numerically, the clotting time (a) at zero incubation time and the clotting time (b) after an arbitrary incubation time $(\mathrm{c})$ are indicated by the notation $t_{\mathrm{o}-\mathrm{e}}(\mathrm{a} ; \mathrm{b})$. Thus $\mathrm{t}_{0-2}(80 ; 69)$ means that in a given experiment the thrombotest time at zero time was 80 seconds and after two hours 69 seconds. The values called zero-time values were obtained as quickly as possible after mixing in the kaolin (between 10 and $30 \mathrm{sec}$ ). Fig. 1 and 2 and Table 1 show that a concentration of $0.156 \mathrm{mg}$ kaolin per $\mathrm{ml}$ incubation mixture ensures maximal activation of the thrombotest time and minimal absorb-

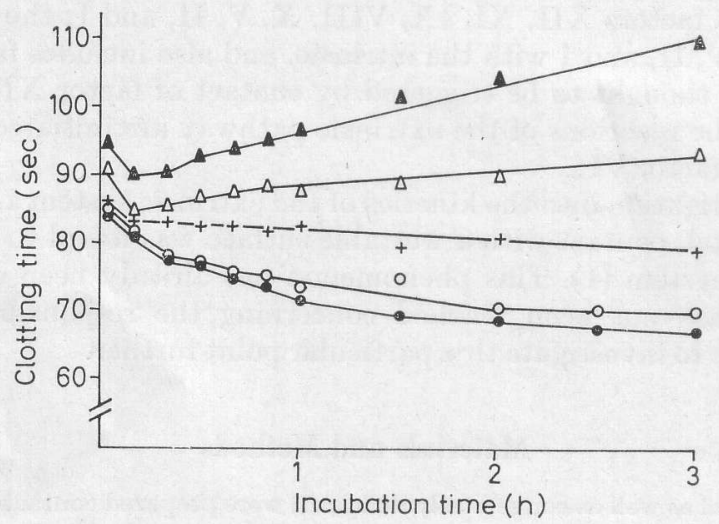

Fig. 1. The activation of the thrombotest reaction in normal plasma ( $1: 10$ dilution) after incubation with various concentrations of kaolin. $\triangle 5 \mathrm{mg} / \mathrm{ml} ; \triangle 3.75 \mathrm{mg} / \mathrm{ml} ;+0.05 \mathrm{mg} / \mathrm{ml} ; \bigcirc 0.10 \mathrm{mg} / \mathrm{ml}$; $0.156 \mathrm{mg} / \mathrm{ml}$.

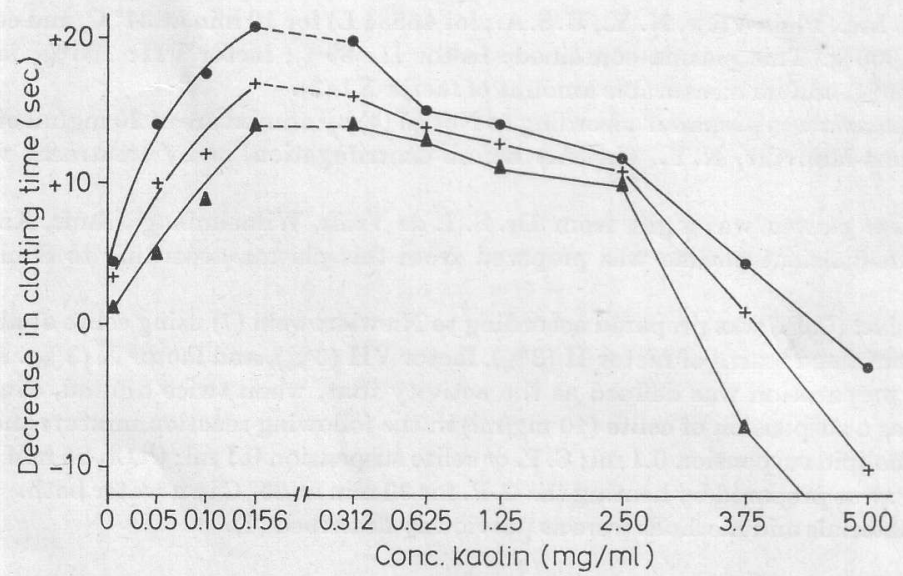

Fig. 2. The activation of the thrombotest reaction in normal plasma (1:10 dilution) by incubation with kaolin. 
Table 1. The Effect of Incubation with Kaolin on the Clotting Factors of Normal Plasma.

\begin{tabular}{c|c|c|c|c|c}
\hline $\begin{array}{c}\text { Conc. of } \\
\text { Kaolin } \\
(\mathrm{mg} / \mathrm{ml})\end{array}$ & $\begin{array}{c}\text { Incubation } \\
\text { time (min) }\end{array}$ & F. II & F. V & F. VII & F. X \\
\hline 0. & 240 & 8.4 & 5.8 & 9.8 & 8.4 \\
0.156 & 240 & 7.5 & 6.0 & 11.5 & 7.4 \\
0.312 & 240 & 6.5 & 3.2 & 10.2 & 5.8 \\
0.625 & 90 & 5.8 & 1.7 & 9.6 & 5.6 \\
1.250 & 120 & 6.1 & 1.7 & 5.8 & 6.4 \\
2.500 & 180 & 6.4 & .25 & 3.6 & 4.2 \\
3.750 & 240 & 4.2 & -02 & 2.3 & .7 \\
5.000 & 300 & 3.4 & .02 & 1.6 \\
\hline
\end{tabular}

One in 10 diluted normal plasma was incubated with kaolin. After the incubation time the plasma was centrifuged for $10 \mathrm{~min}$ at $20.000 \mathrm{~g}$. The clotting factor concentration was determined and expressed in \% of the same normal pool plasma the experimental sample originated from.

ance of clotting factors. Consequently, this concentration was used in further experiments. At this concentration of kaolin it made no difference whether the sample was incubated in a glass or a plastic tube. Even at a lower kaolin concentration $(0.10 \mathrm{mg} / \mathrm{ml})$ no differences were found, as can be seen from the following figures: in glass, $\mathrm{t}_{0^{-}} 1$ $(83 ; 79) ; \mathrm{t}_{0^{-} 2}(83 ; 78) ; \mathrm{t}_{0^{-} 3}(83 ; 71)$; in plastic, $\mathrm{t}_{0^{-} 1}(83 ; 78) ; \mathrm{t}_{0^{-}}(83 ; 76) ; \mathrm{t}_{0^{-} 3}(83 ; 71)$; (means of sixfold estimations).

To determine the pathway of contact activation in the extrinsic system, the activation of various deficient plasmas was investigated. For plasmas deficient in factors, II, VII, and X, the test procedure had to be modified because of the sensitivity of the thrombotest reaction for these factors. In these cases the 1 in 10 dilution of deficient plasma was incubated with kaolin, but the test was carried out by subsampling into $0.5 \mathrm{ml}$ thrombotest, together with $0.05 \mathrm{ml}$ of a 1 in 10 dilution of fresh normal, noncontacted plasma.

The results are shown in Table 2, from which it can be seen that factor XII and factor VII are absolutely necessary for activation of the extrinsic system, whereas

Table 2. Contact Activation of the Extrinsic System in Deficient Plasmas.

\begin{tabular}{l|r|r|r|r|r|r}
\hline \multicolumn{1}{c|}{ Plasma } & $\mathrm{t}_{\mathbf{0}}$ & $\mathrm{t}_{\mathbf{1} / \mathbf{2}}$ & $\mathrm{t}_{\mathbf{1}}$ & $\mathrm{t}_{\mathbf{2}}$ & $\mathrm{t}_{\mathbf{4}}$ & $\mathrm{t}_{\mathbf{0}}-\mathrm{t}_{\mathbf{4}}$ \\
\hline F. XII deficient & 83 & 83 & 82 & 82 & 79 & 4 \\
F. XI deficient & 101 & 98 & 95 & 92 & 90 & 11 \\
F. X deficient & 97 & 91 & 89 & 84 & 79 & 18 \\
F. IX deficient & 97 & 87 & 83 & 78 & 72 & 25 \\
F. VIII deficient & 89 & 82 & 77 & 72 & 66 & 23 \\
F. VII deficient & 96 & 97 & 95 & 94 & 93 & 3 \\
F. V deficient & 109 & 104 & 98 & 94 & 92 & 17 \\
F. II deficient & 93 & 89 & 82 & 78 & 76 & 17 \\
Normal plasma & 86 & 77 & 72 & 69 & 65 & 21 \\
Normal plasma + 3 mM EDTA & 83 & 76 & 73 & 67 & 63 & 20 \\
\hline
\end{tabular}

The tests were carried out as described in the text. The subscript of $t$ denotes the incubation time. The final concentration of kaolin was $0.156 \mathrm{mg} / \mathrm{ml}$. The figures are derived from triplicate experiments, where the thrombotest time of the plasma under investigation was measured every $10 \mathrm{~min}$. 


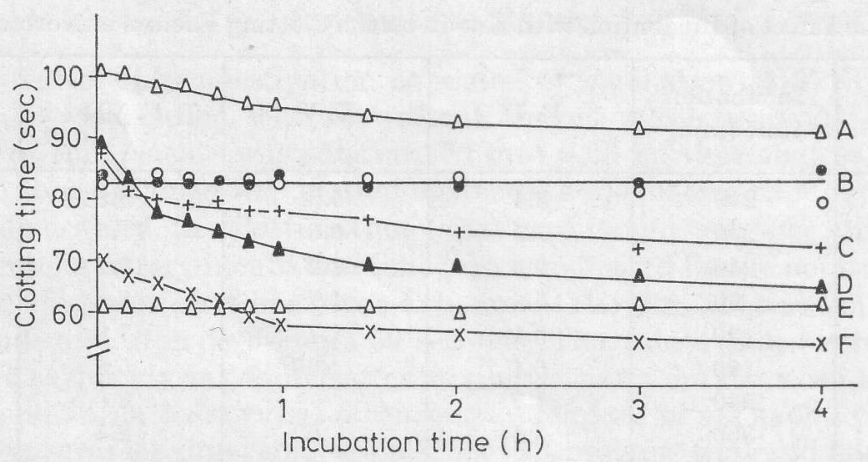

Fig. 3. The activation of the thrombotest reaction by incubation with $0.156 \mathrm{mg} / \mathrm{ml} \mathrm{kaolin}$ in various plasmas. A Factor XI-deficient plasma; B Exhausted and non-exhausted factor XIIdeficient plasma; C Improved factor XI-deficient plasma; D Normal plasma; E Exhausted normal plasma; F Ba-stearate-absorbed plasma.

factors X, IX, VIII, V, and II are not. The results of the experiment with factor XIdeficient plasma indicate that activation of VII is possible without factor XI, but that the presence of factor XI enhances the activation. This is emphasized by Fig. 3, which shows not only that congenitally factor XI-deficient plasma is capable of activation, but also that after absorption with celite $(5 \mathrm{mg} / \mathrm{ml})$ to remove possible traces of factor XI, this capability was still present. Ba-stearate-absorbed plasma, which contained no measurable amounts of factor XI, was capable of activation in the extrinsic system. Ba-stearate, it should be noted, seems to activate plasma to a certain degree. The process that brings about "exhaustion" of normal plasma (10 min incubation at $37^{\circ} \mathrm{C}$ in the presence of $30 \mathrm{mg} / \mathrm{ml}$ celite) apparently causes maximal activation of the extrinsic system, but it has no effect on factor XIT-deficient plasma. The contact product (C.P.) prepared according to Niewiarowski (7) can cause activation of factor XII-deficient plasma in the absence of kaolin (Fig.4). When heated for $30 \mathrm{~min}$ at $65^{\circ} \mathrm{C}$, the C. P. lost its activity either to activate the exhausted Hageman plasma

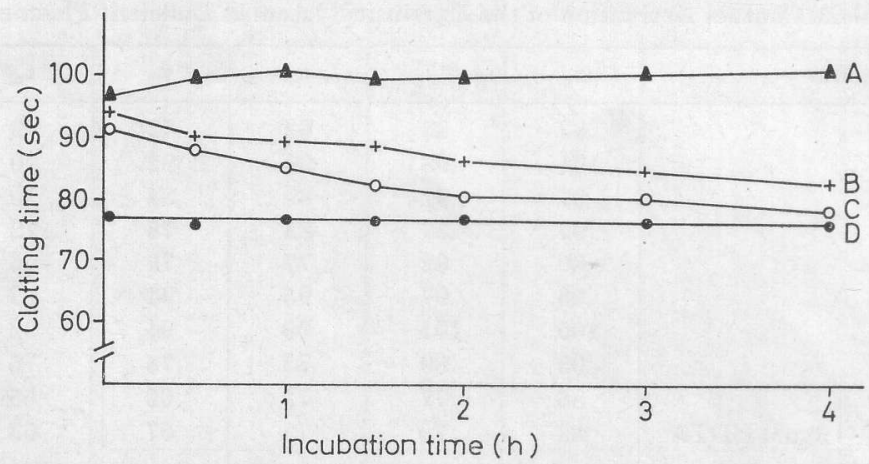

Fig. 4. The activation of the thrombotest reaction by addition of contact product in various plasmas. A Exhausted factor XII-deficient plasma with added C.P., after heating at $65^{\circ} \mathrm{C}$ for $30 \mathrm{~min}$; B Exhausted factor XII-deficient plasma; C Factor XII-deficient plasma; D Exhausted normal plasma. 
(Fig.4) to correct a factor XII- or factor XI-deficient plasma. The degree of activation was quantitatively related to the amount of factor XII and the amount of C.P. (Fig.5). The variation of factor XII was brought about by mixing normal and factor XII-deficient plasma. C. P. was added to exhausted factor XII-deficient plasma in the other series of experiments.

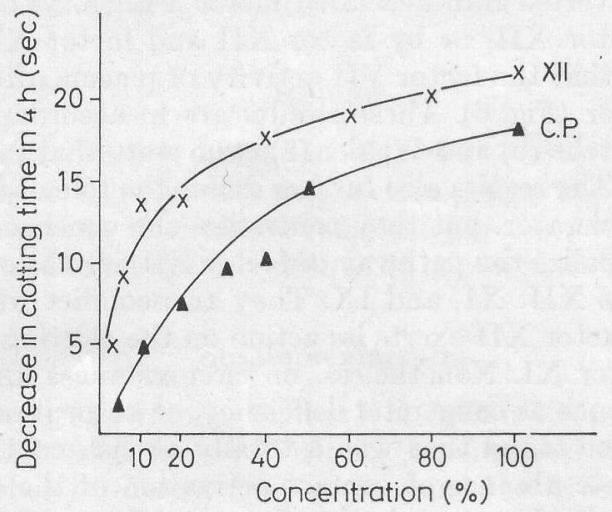

Fig. 5. The influence of the concentration of factor XII and contact product on the activation of factor XII-deficient plasma.

The extent of activation was also dependent upon the amount of factor VII present. It was not possible to express this in a simple relationship, as was done for factor XII and C. P. Consequently, Fig. 6 shows the relationship between the amount of factor VII known to be present at zero time and the amount apparently present after 4 hrs of activation by kaolin.

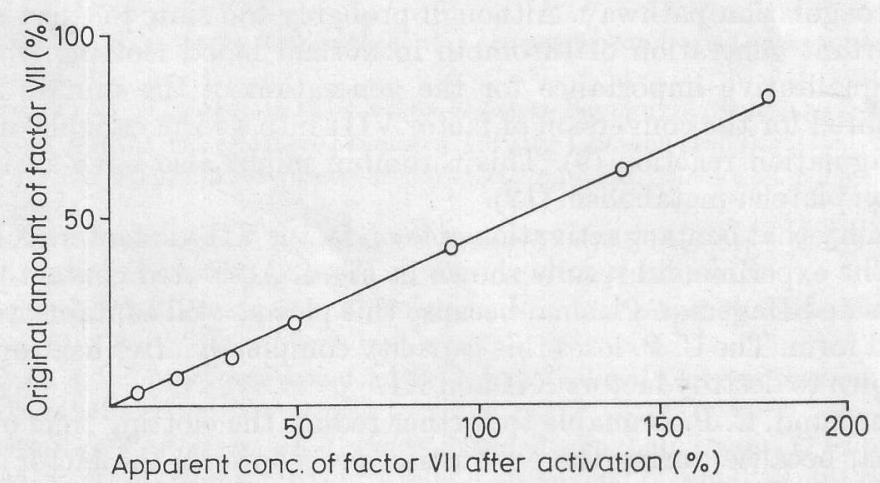

Fig. 6. The influence of activation on the apparent amount of factor VII in mixtures of normal and factor VII-deficient plasmas.

Incubation with neutralized thorium chloride did not prevent activation, as can be seen from the following figures: with $\mathrm{ThCl}: \mathrm{t}_{0^{-} 3}(85 ; 74)$; without $\mathrm{ThCl}: \mathrm{t}_{0^{-} 3}(84 ; 72)$; (mean of 6 estimations). 


\section{Discussion}

The experimental results indicate that contact, as produced by glass or kaolin, shortens the clotting time in a thrombotest system by a mechanism dependent upon factor XII and factor VII. The other clotting factors are not compulsatory for this phenomenon, although factor XI has a clear-cut accelerating effect. This suggests that factor VII can be converted into activated factor VII (F. VII ) not only by tissue factor but also by factor XII, or by factor XII and factor XI together. This also appears from the fact that the factor VII activity of plasma after contact activation was found to be higher (Fig. 6). These results are in accordance with the view of Soulier and Prou-Wartelle (6) and Waaler (8), who state that factor XII is compulsatory for this process. The results also further define the role of factor XI as that of a non-compulsatory accelerator, but they contradict the conclusion of Shanberge and Matsuoka (2), who visualize the pathway of factor VII activation by foreign surfaces as mediated by factors XII, XI, and IX. They also conflict with the intuitive idea that in all likelihood factor XII exerts its action on the clotting mechanism via or in combination with factor XI. Nonetheless, no circumstances known to promote the absence of factor XI, such as congenital deficiency, or absorption with Ba-stearate of normal plasma could be found that would totally abolish contact activation of the system tested. Complete absence of contact activation of the extrinsic system was found only in the absence of contact, in the absence of factor XII, or in the absence of factor VII. Yet factor XI does play a role in factor VII activation in normal blood, since its presence markedly enhances the contact activation observed. Therefore, both the following reaction schemes seem possible:

(a)
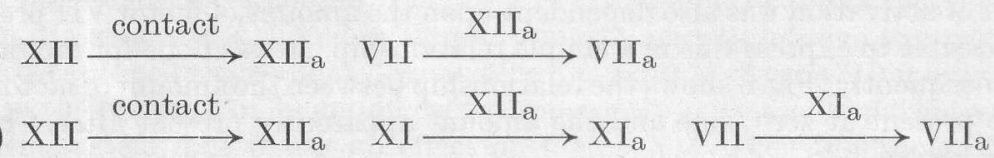

It is interesting to note that these reaction sequences constitute a short-circuit of the intrinsic coagulation pathway. Although probably too slow to exert any quantitatively important generation of thrombin in normal blood clotting, this pathway might be of qualitative importance for the generation of the minute amounts of thrombin required for the conversion of factor VIII into a form capable of participating in the coagulation reaction (9). This thrombin might also have an influence on factor $V$ and on platelet metabolism (12).

The probability that contact activation acts on factor VII via factors XII and XI is increased by the experimental results shown in Fig. 4. Activated contact product can activate exhausted Hageman Plasma, because this plasma still contains its factor VII in unactivated form. The C. P. loses this capacity completely after heating to $65^{\circ} \mathrm{C}$, a procedure known to destroy factors XII and XI.

On the other hand, C. P. is unable to further reduce the clotting time of exhausted normal plasma, because during the exhaustion procedure all the factor VII in that plasma has already been converted into its active form. $\mathrm{Ca}^{++}$did not appear to be necessary for the activation, since $3 \mathrm{mM}$ EDTA had no inhibitory effect (Table 2).

We are unable to put forward a hypothesis to explain the difference between the findings of Shanberge \& Matsuoka and our own experiments with respect to the role of factor IX in the activation of factor VII. The possibility must be kept in mind that another factor (Tatsumi factor ?) plays a role in the process. Thorium chloride or thorium hydroxide did not inhibit the activation. 


\section{Summary}

After contact activation, factor XII can convert factor VII into its active form. Factor XT enhances this action but appears not to be a compulsatory part of the system. The short circuit of the intrinsic system constituted by this pathway may be important in triggering the intrinsic coagulation system.

\section{Résumé}

Après activation par contact, le facteur XII peut convertir le facteur VII en sa forme active. Le facteur XI augmente cette action mais n'apparaît pas indispensable. Le court circuit du système intrinsèque constitué par cette voie peut être important dans le déclenchement du système intrinsèque de la coagulation.

\section{Zusammenfassung}

Nach Kontaktaktivierung vermag Faktor XII Faktor VII in seine aktive Form umzuwandeln. Faktor XI steigert diese Wirkung, scheint aber kein unbedingt notwendiger Reaktionspartner in diesem System zu sein. Der Kurzschluß des endogenen Systems, der durch diesen Weg hergestellt wird, könnte für die Aktivierung des endogenen Gerinnungssystems von Bedeutung sein.

\section{Acknowledgements}

While this work was being carried out, one of us (R.A.) held a fellowship under the Netherlands Fellowship Programme for Technical Cooperation (NFP 1979). Rewarding discussions with Dr. E. A. Loeliger are gratefully acknowledged. Mrs. Hella van Hoorn has been a great help in preparing the manuscript.

\section{References}

(1) Hemker, H.C., R. Altman, T. Siepel, E. A. Loeliger: Thrombosis Diathes. haemorrh. (Stuttg.) 17: 349 (1967).

(2) Shanberge, J. N., T. Matsuoka: Thrombos. Diathes. haemorrh. (Stuttg.) 15: 442 (1966).

(3) Vroman, L.: Thrombos. Diathes. haemorrh. (Stuttg.) 10: 455 (1963).

(4) Nossel, H. L.: The contact phase of blood coagulation. Blackwell Scientific Publications, Oxford 1964

(5) de Vries, S. I., J. Braat-van Straaten: Thrombos. Diathes. haemorrh. (Stuttg.) 11: 167 (1964).

(6) Soutier, J. P., O. Prou-Wartelle: Brit. J. Haemat. 6: 88 (1960).

(7) Niewiarowski, S., J. Stachurska, Z. Wegrzynowicz: Thrombos. Diathes. haemorrh. (Stuttg.) $7: 514$ (1962).

(8) Waaler, B. A.: Contact activation in the Intrinsic Blood Clotting System. Oslo University Press, Oslo 1959.

(9) Rapaport, S. I., P.F. Hjort, M. J. Patch: Scand. J. clin. Lab. Invest. 17 (suppl. 84): 88 (1965)

(10) Newcomb, T. F., M. Hoshida: Scand. J. clin. Lab. Invest. 17 (suppl. 84): 61 (1965).

(11) Bergsagel, D. E., E. R. Nockolds: Brit. J. Haemat. 11: 395 (1965).

(12) Käser-Glanzmann, R., E. F. Lüscher: Thrombos. Diathes. haemorrh. (Stuttg.) \%: 480 (1962).

Received for publication January 11, 1967

Copyright by F. K. Schattauer Verlag, Stuttgart - Der Verlag behält sich alle Rechte, besonders die des Nachdrudkes, der Vervielfältigung und der Ubersetzung vor. 